\title{
Axon-Like Processes Within the Lateral Ventricle of Cat (Corpus Callosum and Nucleus Caudatus)
}

Intraventricular axon-like processes have been described in some regions of the III. and IV. ventricle ${ }^{1-9}$. These observations have not made clear whether the nerve endings are restricted in special areas of the ventricular surfaces. An electronmicroscopical study of the ventricular lining demonstrated that similar processes also exist in the lateral ventricles of cats (Figure). Furthermore, they do not only occur in those regions where ependyma covers grey substance (nucleus caudatus) but also at the ependymal lining of the corpus callosum.

The intraventricular processes showing a beaded shape consist of small parts (diameter $0.2-0.6 \mu \mathrm{m}$ ) which contain microtubules and filaments and thicker parts. The latter represent varicosities which are filled with small clear vesicles, dense core granules, larger dense granules and mitochondria. The varicosities make desmosomelike contacts with the apical surface of the ependymal cells. They differ from typical synapses by the lack of vesicle aggregates at the presynaptic membrane. On the other hand, they are embraced by locally accumulated microvilli arising from ependyma.

The larger granules and dense core granules of the same size as in intraventricular processes occur in epen- dymal cells, too. They are more numerous in ependyma of nucleus caudatus than of corpus callosum. Predominantly they were found in the apex and in processes, by which the ependymal cells interdigitate. In some cases, the neuronal origin of intraventricular processes seems to be certain 7 . In our material several processes certainly originate from ependymal cells. But in some cases the origin cannot be determined because of their similar ultrastructure. The origin of intraventricular axon endings, especially at the surface of the corpus callosum, is unknown. A neurosecretory function, as suggested, from the infundibular region ${ }^{8,10,11}$ seems to be very improbable in corpus callosum. Irrespective of their origin, the general synaptic function of their contacts may be questioned. At least in the regions considered here, the typical synaptic complex has not been found. Since ependymal cells locally surround the contact by microvilli, which represent a surface specialization known from epithelial cells with a resorptive or a receptory function ${ }^{12}$, one could speculate on a receptory mechanism acting on the apical surface of ependyma. This should be different from typical innervation at its basis ${ }^{13,14}$. Agent, mechanism of action, and significance of such a process is still unknown.
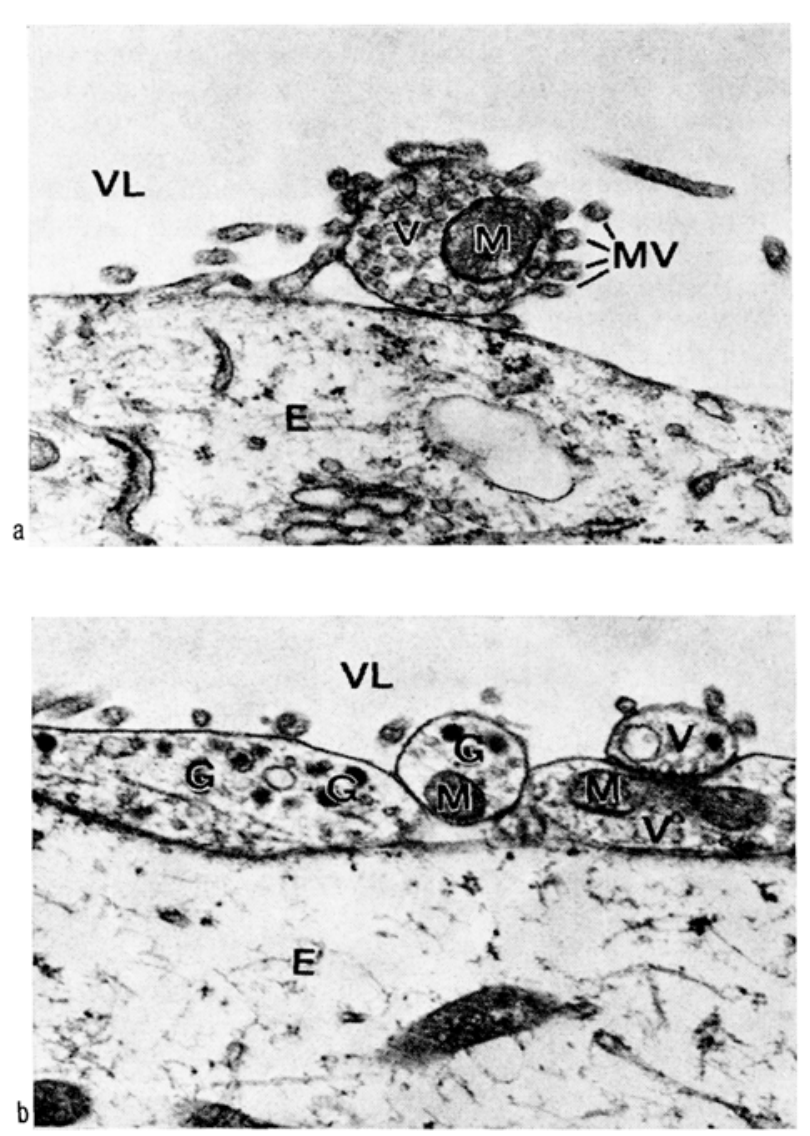

Axon-like processes occur within the lumen of the lateral ventricle. The contacts of the processes with the apex of the ependymal cells are surrounded by microvilli. V, vesicles; $G$, dense core granules; $M$, mitochondria; $E$, ependyma; VL, lumen of the ventricle. a) $\times 40,000$; b) $\times 30,000$.
Zusammenfassung. In den Seitenventrikeln wurden intraventrikuläre Zellfortsätze beobachtet. Ein Teil davon ähnelt Neuritenendigungen, wie sie bereits von anderen Autoren im III. und IV. Ventrikel beobachtet wurden. Sie enthalten die typischen Bestandteile präsynaptischer Elemente; die Vesikel sind jedoch nicht an den desmosomenartigen Kontakten mit dem Ependymapex aggregiert. Ihre Umhüllung mit Mikrovilli könnte für eine Rezeptorfunktion sprechen. Andere Fortsätze sind ependymaler Herkunft.

W. NOACK and J. R. WOLFF

Forschungsabteilung für Elektronenmikroskopie der Freien Universität Berlin,

Königin-Luise-Strasse 15, D-1 Berlin 33 (Germany), 20 July 1970
1 D. Tretjakofe, Arch. mikrosk. Anat. 74, 636 (1909).

2 D. Tret JAkoff, Arch. mikrosk. Anat. 83, 68 (1913).

${ }^{3}$ C. A. Fox, W. ZEIT, S. DE SAlva and R. Fisher, Anat. Rec. $100,767(1948)$.

4. W. Brightman and S. L. Palay, J. Cell Biol. 19, 415 (1963).

5 U. K. Rinne, Z. Zellforsch. 74, 98 (1966).

6. LeOnhaRdT, Z. Zellforsch. 79, 172 (1967).

${ }^{7}$ H. LeONHARDT, Z. Zellforsch. 84, 1 (1968)

8 W. Wirtkowski, Z. Zellforsch. 92, 207 (1968)

- H. Leonhardt and A. Backnus-Roth, Z. Zellforsch. 97, 369 (1969).

10 D. Erchner, Z. mikrosk. anat. Forsch. 69, 388 (1963),

11 H. Altwer, Z. Zellforsch. 73, 10 (1966).

12 D. W. FAwCETT, J. Histochem. Cytochem. 13, 75 (1965).

13 F. KNowles and L. VollRath, Nature, Lond. 208, 1343 (1965). $14 \mathrm{~F}$. KNowles, IV. Internat. Sympos. on Neurosecretion (Ed. F. Stubinsky; J. Springer-Verlag, Berlin, Heidelberg, New York 1967), p. 8. 